\title{
Obstetrics and Gynecology Modified Delphi Survey for Entrustable Professional Activities: Quantification of Importance, Benchmark Levels, and Roles in Simulation- based Training and Assessment
}

Milena Garofalo $^{1}$, Rajesh Aggarwal ${ }^{2}$

1. Obstetrics and Gynaecology, Medicine/McGill University Health Centre, Montreal, CAN 2. Surgery, Strategic Business Development/Thomas Jefferson University and Jefferson Health, Philadelphia, USA

$\square$ Corresponding author: Milena Garofalo, milena.garofalo@mail.mcgill.ca Disclosures can be found in Additional Information at the end of the article

\section{Abstract}

\section{Objective}

Competency-based medical education (CBME) is playing a central role in physicians' training. It focuses on competencies, measured by entrustable professional activities (EPAs). The aim of this survey is threefold for each EPA to (1) quantify the importance for Obstetrics and Gynecology (OBGYN) residency training; (2) set benchmarks; (3) identify the importance of simulation-based training (SBT).

\section{Methods}

The EPAs were defined based on a review of five OBGYN curricula. Two rounds of a modified Delphi via online questionnaire were performed from January to March, 2017. Experts were North American OBGYN program directors. Using a Likert scale, they rated the importance of each EPA for residency training, identified benchmark levels of competence, and roles of simulation. Consensus was defined as $\geqslant 80 \%$ agreement.

\section{Results}

Item analysis yielded 15 EPAs. Survey response rate was $17.47 \%$ (40 out of 229 ) for part 1 and $6.55 \%$ for part 2 (15 out of 229). All experts rated the importance of each EPA for residency training as "moderately important" or “absolutely essential”. For benchmarking, experts agreed with a stepwise increase in the level of competence, dependent on residency stage. Two EPAs,

Received 07/12/2018 Review began 07/13/2018 Review ended 07/22/2018 Published 07/25/2018

\section{(c) Copyright 2018}

Garofalo et al. This is an open access article distributed under the terms of the Creative Commons Attribution License CC-BY 3.0., which permits unrestricted use, distribution, and reproduction in any medium, provided the original author and source are credited.
"Gynecological Technical Skills \& Procedures" and "High-Risk Childbirth", reached consensus (rating 4 or 5) for simulation.

\section{Conclusion}

CBME requires EPAs and benchmarks for each residency stage. Simulation will become a valuable tool in this model. However, experts remain neutral about its role, except for technical skills. An OBGYN curriculum based on predefined EPAs, benchmarks, and adequate assessment tools, including simulation, needs to be further explored for CBME to be successful.

Categories: Medical Education, Obstetrics/Gynecology

\section{How to cite this article}

Garofalo M, Aggarwal R (July 25, 2018) Obstetrics and Gynecology Modified Delphi Survey for Entrustable Professional Activities: Quantification of Importance, Benchmark Levels, and Roles in Simulation-based Training and Assessment. Cureus 10(7): e3051. DOI 10.7759/cureus.3051 
Keywords: simulation, competency-based education, obstetrics, gynecology, epa

\section{Introduction}

Competency-based medical education (CBME) plays a central role in today's training of physicians [1-4]. The concept of CBME is to ensure stages of training, with a focus on specific acquisition of competencies, is measured by entrustable professional activities (EPAs) and milestones [5-6]. Competencies are defined as "the synthesis of knowledge, skills, and attitudes that are reflected in professional activities" [7]. The concept of EPA was introduced by Ten Cate \& Scheele in 2007 in order to "bridge the gap between competency-driven education and clinical practice" because "competencies are intertwined in complex ways that make them less explicit and measurable" [3,5]. An EPA is a specific task or activity that can be 'entrusted' to a person once sufficient competence has been achieved. EPAs represent day to day work; they are executable, observable, and measurable entities and can be the focus of assessment [8]. A milestone is defined as "an observable marker of an individual's ability" [6,9]. Typically each EPA integrates multiple competencies and milestones [5-6,8-9].

Based on a review of national Obstetrics and Gynecology (OBGYN) residency curricula from five countries (Australia, Canada, Netherlands, UK, and the USA), it was concluded that all curricula have or will be integrating CBME into their training programs [10]. Nonetheless, there is a need to develop adequate training and assessment tools, including simulation, to ultimately deliver competent physicians, capable of unsupervised practice. Although some programs within Canada have already started piloting CBME and EPAs, [11] the national Canadian "Competence By Design” (CBD) program is expected to roll-out officially for OBGYN in 2019 [9].

Assessment of clinical competence can be done in a variety of ways based on four levels, as shown in Miller's pyramid [12]. The lower cognitive levels "knows" and "knows how", typically assessed by written and oral exams, do not ensure that knowledge is transferred into competence. This contrasts with the higher behavioural levels of Miller's pyramid, "shows how" and "does", where competence can be demonstrated. Examples include simulation, Objective Structured Clinical Examination and Assessment of Technical Skills (OSCE/OSATS) and workplace based assessments (WBAs). Simulation may serve as an additional or alternative outlet to WBAs since these remain a challenge in everyday clinical practice. Simulation will thus be a valuable tool in the training and assessment of residents in the CBD program, allowing direct observation of many technical and non-technical skills. It allows the opportunity to improve performance by mimicking reality in a safe learning environment [13$15]$.

The aims of this Delphi survey are threefold: first, quantify the importance of each pre-defined EPA with respect to OBGYN residency training; second, set benchmark levels for each EPA; and third, identify the importance of simulation-based training and assessment for each EPA. The ultimate goal is to provide a framework for building a national curriculum based on predefined EPAs and benchmarks levels at each stage of residency training, and develop training and assessment tools using simulation. This was based on expert consensus using a modified Delphi consensus method.

\section{Materials And Methods}

We defined the individual items (EPAs) used in the survey based on a review of five international OBGYN curricula [10]. This process was undertaken with the engagement of a medical educator and an OBGYN clinician. We established that the EPAs defined in the Dutch curriculum would be the framework, since it most closely resembles the Canadian model [7] (Figure 1). We excluded potential EPAs that constituted general characteristics that could be part of the description and milestones for other more specific OBGYN EPAs (e.g., ethical and 


\section{Cureus}

legal issues, patient safety, communication) (Figure 2). We performed two rounds of a modified Delphi survey via online questionnaire through "Survey Monkey" to (1) rate the importance of each EPA for residency training, (2) rate the importance of simulation-based training and assessment for each EPA and (3) identify benchmark levels of competence, for each specified stage of residency training. Experts in the study were OBGYN residency program directors across Canada and the United States (US), who received an email request to participate in an online questionnaire. Experts were asked to rate the importance of each EPA for residency training based on a Likert scale from 1 to 5 :

1. Not at all important

2. Minimal importance

3. Neutral

4. Moderately essential

5. Absolutely essential

\begin{tabular}{|c|c|c|c|c|}
\hline Netherlands & Australia & USA & UK & Final EPA \\
\hline \multirow[t]{2}{*}{$\begin{array}{l}\text { Uncomplicated Antenatal } \\
\text { Care }\end{array}$} & & & Antenatal Care & \multirow[t]{2}{*}{$\begin{array}{l}\text { 1. Uncomplicated antenatal \& } \\
\text { prenatal care }\end{array}$} \\
\hline & & & Early pregnancy care & \\
\hline Complicated Antenatal Care & & $\begin{array}{l}\text { Antepartum Care \& } \\
\text { Complication of pregnancy }\end{array}$ & Maternal Medicine & $\begin{array}{l}\text { 2. Complicated antenatal \& } \\
\text { prenatal care }\end{array}$ \\
\hline \multirow[t]{2}{*}{ Intrapartum Care } & & $\begin{array}{l}\text { Patients in the intrapartum } \\
\text { period }\end{array}$ & Management of labor & 3. Intra partum Care \\
\hline & Obstetrical technical skills & Obstetrical technical skills & Management of delivery & 4. Childbirth \\
\hline $\begin{array}{l}\text { Complicated Childbirth } \\
\text { Basic high risk childbirth }\end{array}$ & & & & 5. High risk childbirth \\
\hline $\begin{array}{l}\text { Complicated postpartum \& } \\
\text { newborn care }\end{array}$ & & $\begin{array}{l}\text { Immediate care of the } \\
\text { newborn }\end{array}$ & $\begin{array}{l}\text { Postpartum problems } \\
\text { (the pueperium) }\end{array}$ & \multirow[t]{2}{*}{ 6. Postpartum \& newborn care } \\
\hline $\begin{array}{l}\text { Uncomplicated postpartum } \\
\text { \& newborn care }\end{array}$ & & $\begin{array}{l}\text { Patients in the postpartum } \\
\text { period }\end{array}$ & Gynecological problems & \\
\hline \multirow[t]{4}{*}{$\begin{array}{l}\text { Benign outpatient } \\
\text { gynecology }\end{array}$} & & Ambulatory gynecology & & \multirow[t]{4}{*}{ 7. Benign Gynecology } \\
\hline & & First trimester bleeding & & \\
\hline & & $\begin{array}{l}\text { Abdom inal pelvic pain } \\
\text { (acute \& chronic) }\end{array}$ & & \\
\hline & & $\begin{array}{l}\text { Abnormal uterine bleeding } \\
\text { (acute \& chronic) }\end{array}$ & & \\
\hline Peri-operative care & & $\begin{array}{l}\text { Informed consent \& shared } \\
\text { decision making }\end{array}$ & & 8. Pre-operative care \\
\hline \multirow[t]{6}{*}{ Basic surgery } & Laparoscopic surgery & $\begin{array}{l}\text { Gynecological technical } \\
\text { skills: endoscopy }\end{array}$ & Core surgical skills & \multirow[t]{5}{*}{$\begin{array}{l}\text { 9. Gynecological technical skills } \\
\text { \& procedures }\end{array}$} \\
\hline & $\begin{array}{l}\text { Open abdominal } \\
\text { gynecological surgery }\end{array}$ & $\begin{array}{l}\text { Gynecological technical } \\
\text { skills: laparotomy }\end{array}$ & Surgical procedures & \\
\hline & Vaginal surgery & $\begin{array}{l}\text { Gynecological technical } \\
\text { skills: vag inal surgery }\end{array}$ & & \\
\hline & $\begin{array}{l}\text { Endometrial inspection, } \\
\text { sampling, and } \\
\text { hysteroscopy }\end{array}$ & & & \\
\hline & $\begin{array}{l}\text { Miscellaneous general } \\
\text { gyne procedures }\end{array}$ & & & \\
\hline & & & Postoperative care & 10. Postoperative care \\
\hline $\begin{array}{l}\text { Basic urogynecology \& pelvic } \\
\text { floor problems }\end{array}$ & & Pelvic floor disorders & $\begin{array}{l}\text { Urogyneocology \& pelvic } \\
\text { floor problems } \\
\end{array}$ & $\begin{array}{l}\text { 11. Urogynecology \& pelvic } \\
\text { floor problems }\end{array}$ \\
\hline \multirow[t]{2}{*}{ Basic Reproductive medicine } & & & Subfertility & $\begin{array}{l}\text { 12. Sexual \& Reproductive } \\
\text { Health }\end{array}$ \\
\hline & & & & $\begin{array}{l}\text { 13. Ped iatric \& adolescent } \\
\text { gynecology } \\
\end{array}$ \\
\hline Vulnerable elderly & & & & 14. Mature Women's Health \\
\hline \multirow[t]{2}{*}{ Basic oncology } & $\begin{array}{l}\text { Gynecological oncology } \\
\text { procedures }\end{array}$ & \multirow[t]{2}{*}{ Pelvic Mass } & \multirow[t]{2}{*}{ Gynecological oncology } & \multirow[t]{2}{*}{ 15. Gynecological oncology } \\
\hline & Cervix and Dysplasia & & & \\
\hline
\end{tabular}

FIGURE 1: Composite List of Final Entrustable Professional 


\section{Activities (EPA) Based on Review of Literature}

\begin{tabular}{|c|c|c|c|}
\hline Australia & Netherlands & USA & UK \\
\hline & & $\begin{array}{l}\text { Patient Safety \& systems } \\
\text { approach to medical error } \\
\text { Communication with } \\
\text { patients \& family } \\
\text { Accountability \& } \\
\text { responsiveness to the needs } \\
\text { of patients, society, and } \\
\text { profession } \\
\text { Compassion, integrity \& } \\
\text { respect for others } \\
\text { Quality improvement } \\
\text { process } \\
\text { Communication with } \\
\text { physicians \& other health } \\
\text { professionals and } \\
\text { Teamwork } \\
\text { Healthcare maintenance \& } \\
\text { Disease Prevention } \\
\text { Cost-effective care \& } \\
\text { patient advocacy } \\
\text { self-directed } \\
\text { learning/Critical appraisal of } \\
\text { medical literature } \\
\text { Respect for patient privacy, } \\
\text { autonomy, } \\
\text { patient/physician } \\
\text { relationship }\end{array}$ & $\begin{array}{l}\begin{array}{l}\text { Developing } \\
\text { professionalism } \\
\text { Clinical Skills }\end{array} \\
\text { Ethical \& legal issues } \\
\text { Teaching Appraisal \& } \\
\text { Assessment } \\
\begin{array}{l}\text { Information Technology, } \\
\text { Clinical governance \& } \\
\text { Research }\end{array}\end{array}$ \\
\hline
\end{tabular}

FIGURE 2: Discarded List of Entrustable Professional Activities (EPA) Representing General Characteristics

They were then asked to rate the importance of simulation-based training and assessment for each EPA, using the same Likert scale. Finally, the last part of the survey set out to identify benchmark levels of competence, for each specified stage of residency training. We defined the stages of residency training using Eraut's summary of Dreyfus and Dreyfus' model of skill acquisition [16-17] and the US “Milestone Project" levels of observed behavior [18]:

\section{Stage 1: Novice}

Stage 2: Advanced Beginner

Stage 3: Competent

Stage 4: Proficient

We can parallel these to the 4 stages of residency in the Canadian CBD continuum: transition to discipline, foundations of discipline, core of discipline, and transition to practice [19]. We did not include the fifth stage of expert/master as it is expected to reach this stage later in one's career, during continuing professional development. We defined the levels of competence using the competency levels in the Dutch OBGYN curriculum [7], mapped to the Canadian Model and originally based on the instructional scaffolding theory of the zone of proximal development (ZPD) in educational psychology [3,6,20-22]. This theory describes three zones: what a learner can do; what a learner can do with guidance (ZPD); and what a learner can do unaided. 
Level 1: Modeling - has knowledge of

Level 2: Scaffolding - performs with full supervision

Level 3: Fading - performs with limited supervision

Level 4: Entrustment - performs without supervision

Level 5: Able to supervise/teach others

We collected and analyzed responses from this panel of experts. We defined consensus as $\geqslant 80 \%$ agreement for a rating of 4 (moderately essential) and 5 (absolutely essential). Two rounds of the Delphi survey took place. In the second round, experts were told the mean responses from the first round. Ethics approval was granted by the Institutional Review Board (IRB) of the McGill University Faculty of Medicine. This is by itself acceptable for approaching US-based participants as the McGill IRB acts in accordance with the US Code of Federal Regulations and hold an Inter-institutional Agreement.

\section{Results}

The item analysis based on the review of five international OBGYN curricula yielded a list of 15 EPAs:

1. Uncomplicated Antenatal \& Prenatal Care

2. Complicated Antenatal \& Prenatal Care

3. Intrapartum Care

4. Childbirth

5. High Risk Childbirth

6. Postpartum \& newborn care

7. Benign Gynecology

8. Gynecological Technical Skills \& Procedures

9. Pre-operative care

10. Postoperative Care

11. Mature Women's Health

12. Gynecological oncology

13. Urogynecology \& Pelvic Floor Problems

14. Pediatric \& Adolescent Gynecology 


\section{Cureus}

15. Sexual \& Reproductive Health

The overall response rates for the survey were $17.47 \%$ (40 out of 229 ) for part 1 and $6.55 \%$ for part 2 (15 out of 229). Of those that participated in part 1, 17.5\% were Canadian program directors and $82.5 \%$ were American, giving a Canadian response rate of $38.89 \%$ and an American response rate of $15.64 \%$. In part 2, 20\% were Canadian program directors giving response rates of $16.67 \%$ and $80.00 \%$ were American with response rates of $5.69 \%$. Most experts were from academic or university-affiliated community hospitals (Figure 3).

The majority of experts (84.38\% to $100.00 \%)$ experts rated the importance of each EPA for residency training as "moderately important" (4) or "absolutely essential” (5) (Table 1). There was much more variability in the responses when it came to rating the importance for each EPA for simulation-based training and assessment. Only two EPAs had a consensus of $\geqslant 80 \%$ for rating of 4 or 5 for both simulation based training and assessment: "Gynecological Technical Skills \& Procedures" and "High Risk Childbirth". The following highest rated EPA was "Childbirth" at 71.43\%-72.41\% (Tables 2-3). Experts remained "neutral" (mean of 3, Standard Error of the Mean (SEM) 0.17 and 0.15) for all other EPAs, with regards to their importance in simulation as an educational modality for this EPA.

The last part of or survey set out to determine benchmark levels for each EPA at each stage of residency. At Stage 1, the novice learner is expected to be modelling (level 1) or scaffolding (level 2) (mean 1.47-1.56, SEM 0.07-0.08), with $90.48 \%$ to $100.00 \%$ consensus. At Stage 2, the advanced beginner is expected to be scaffolding (level 2) or fading (level 3) (mean 2.49-2.50, SEM 0.09), with $91.67 \%$ to $100.00 \%$ consensus. At Stage 3, the competent learner is expected to be fading (level 3) and be entrusted (level 4) for most EPAs (mean 3.51-3.69, SEM 0.10-0.11), with $83.33 \%$ to $100.00 \%$ consensus. There were two exceptions in Round 1 where consensus was not met: "Postpartum and newborn care" (77.78\%) and "Post-operative care" (77.78\%), suggesting that for these EPAs, the learner may reach level 5 at an earlier stage in training. At Stage 4, the proficient learner is expected to be entrusted (level 4) and can supervise and teach others (level 5) for most EPAs (mean 4.39-4.54, SEM 0.09-0.11), with 80.00\% to $100.00 \%$ consensus (Table 2) (Figure 4).

Part 1 - 40 responses

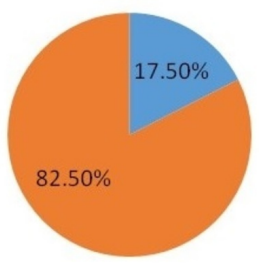

Part 1

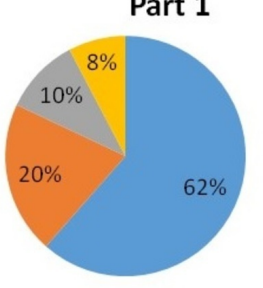

- Canada

- USA
Part 2 - 15 responses

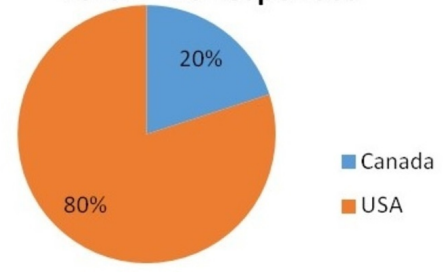

Part 2

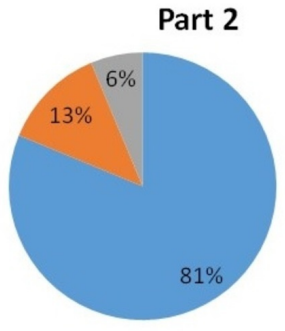

Academic

Community (Universityaffiliated)

- Community (not University-affiliated)

- Other (please specify)

FIGURE 3: Delphi Survey Demographics 


\section{Cureus}
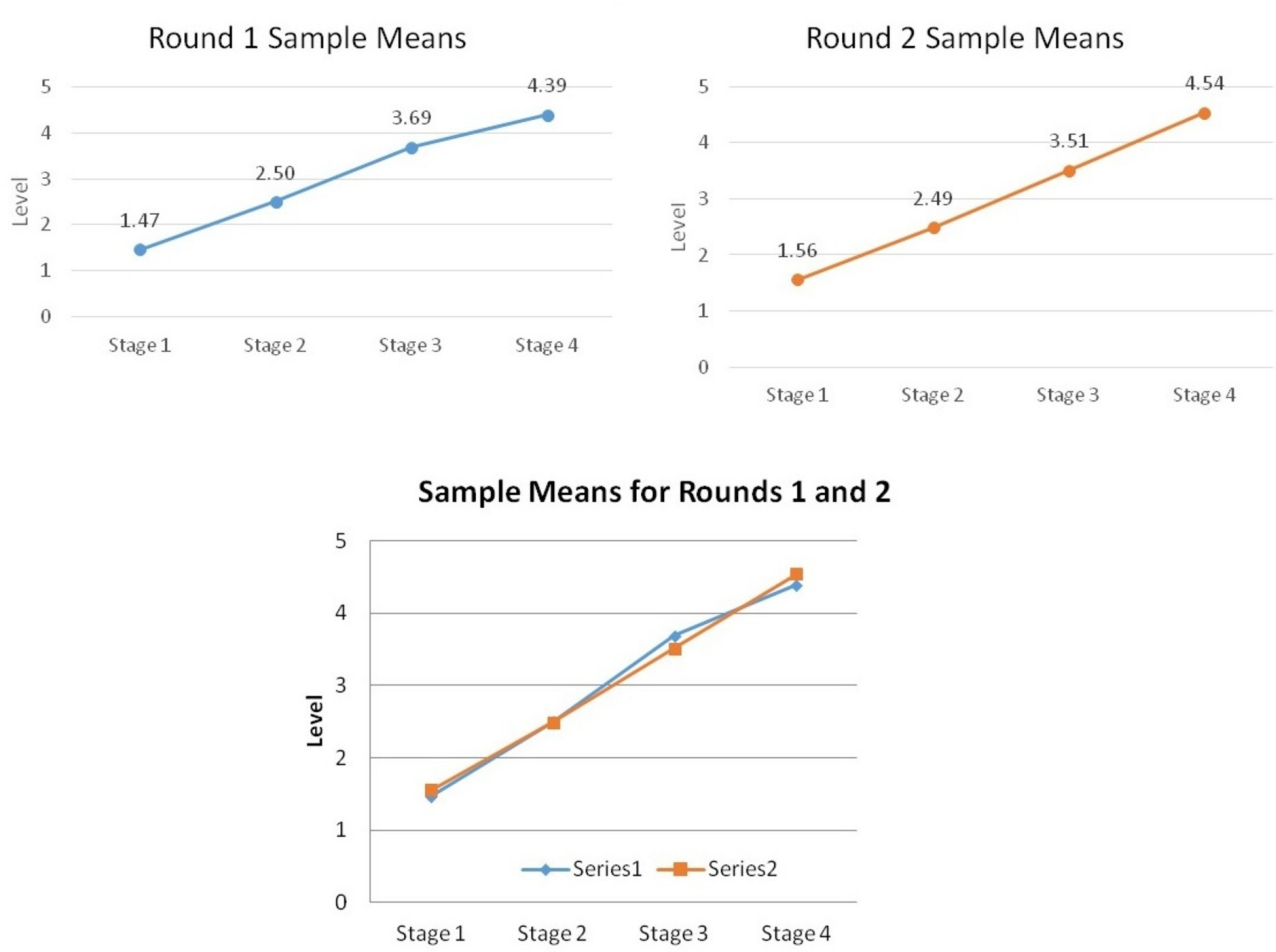

FIGURE 4: Benchmarks for each Entrustable Professional Activity (EPA) - "For each stage of residency training, what is the expected overall mean level of competence?" 


\section{Cureus}

EPA

Uncomplicated Antenatal \& Prenatal Care

Complicated Antenatal \& Prenatal Care

Intrapartum Care

Childbirth

High Risk Childbirth

Postpartum \& newborn care

Benign Gynecology

Gynecological Technical Skills \& Procedures

Pre-operative care

Postoperative Care

Mature Women's Health

Gynecological oncology

Urogynecology \& Pelvic Floor Problems

Pediatric \& Adolescent Gynecology

Sexual \& Reproductive Health

\begin{tabular}{|c|c|c|c|}
\hline \multicolumn{2}{|c|}{ Round 1} & \multicolumn{2}{|c|}{ Round 2} \\
\hline Mean & $\% 4$ or 5 & Mean & $\% 4$ or 5 \\
\hline 4.94 & 100.00 & 5.00 & 100.00 \\
\hline 4.84 & 100.00 & 4.93 & 100.00 \\
\hline 4.94 & 100.00 & 5.00 & 100.00 \\
\hline 4.91 & 100.00 & 5.00 & 100.00 \\
\hline 4.72 & 93.75 & 5.00 & 100.00 \\
\hline 4.5 & 93.75 & 4.86 & 100.00 \\
\hline 4.91 & 100.00 & 5.00 & 100.00 \\
\hline 4.97 & 100.00 & 4.93 & 100.00 \\
\hline 4.78 & 93.75 & 5.00 & 100.00 \\
\hline 4.88 & 100.00 & 5.00 & 100.00 \\
\hline 4.72 & 96.88 & 4.86 & 100.00 \\
\hline 4.41 & 93.75 & 4.57 & 100.00 \\
\hline 4.44 & 93.75 & 4.57 & 100.00 \\
\hline 4.13 & 84.38 & 4.29 & 100.00 \\
\hline 4.55 & 90.32 & 4.64 & 100.00 \\
\hline
\end{tabular}

TABLE 1: Importance of each Entrustable Professional Activity (EPA) for Residency Training 


\section{Cureus}

EPA

Uncomplicated Antenatal \& Prenatal Care

Complicated Antenatal \& Prenatal Care

Intrapartum Care

Childbirth

High Risk Childbirth

Postpartum \& newborn care

Benign Gynecology

Gynecological Technical Skills \& Procedures

Pre-operative care

Postoperative Care

Mature Women's Health

Gynecological oncology

Urogynecology \& Pelvic Floor Problems

Pediatric \& Adolescent Gynecology

Sexual \& Reproductive Health

\begin{tabular}{|c|c|c|c|}
\hline \multicolumn{2}{|c|}{ Round 1} & \multicolumn{2}{|c|}{ Round 2} \\
\hline Mean & $\% 4$ or 5 & Mean & $\% 4$ or 5 \\
\hline 2.14 & 13.79 & 2.43 & 14.29 \\
\hline 2.79 & 31.03 & 2.57 & 14.29 \\
\hline 3.55 & 58.62 & 3.31 & 61.54 \\
\hline 3.72 & 72.41 & 3.57 & 71.43 \\
\hline 4.00 & 75.86 & 4.14 & 92.86 \\
\hline 2.59 & 31.03 & 3.00 & 35.71 \\
\hline 2.83 & 34.48 & 2.92 & 46.15 \\
\hline 4.41 & 89.66 & 4.57 & 100.00 \\
\hline 2.34 & 10.34 & 2.36 & 14.29 \\
\hline 2.72 & 34.42 & 2.50 & 14.29 \\
\hline 2.24 & 6.90 & 2.29 & 14.29 \\
\hline 2.83 & 24.14 & 2.57 & 21.43 \\
\hline 3.17 & 37.93 & 3.29 & 42.86 \\
\hline 2.72 & 24.14 & 2.79 & 28.57 \\
\hline 2.79 & 31.04 & 2.79 & 28.57 \\
\hline
\end{tabular}

TABLE 2: Importance of each Entrustable Professional Activity (EPA) for Simulationbased Training 


\section{Cureus}

\begin{tabular}{|c|c|c|c|c|}
\hline \multirow[t]{2}{*}{ EPA } & \multicolumn{2}{|c|}{ Round 1} & \multicolumn{2}{|c|}{ Round 2} \\
\hline & Mean & $\% 4$ or 5 & Mean & $\% 4$ or 5 \\
\hline Uncomplicated Antenatal \& Prenatal Care & 2.41 & 17.24 & 2.50 & 14.29 \\
\hline Complicated Antenatal \& Prenatal Care & 2.93 & 34.48 & 2.64 & 14.29 \\
\hline Intrapartum Care & 3.48 & 62.07 & 3.15 & 61.54 \\
\hline Childbirth & 3.72 & 72.41 & 3.64 & 71.43 \\
\hline High Risk Childbirth & 3.90 & 75.86 & 4.07 & 85.71 \\
\hline Postpartum \& newborn care & 2.66 & 34.48 & 3.00 & 38.46 \\
\hline Benign Gynecology & 2.90 & 37.93 & 2.79 & 35.71 \\
\hline Gynecological Technical Skills \& Procedures & 4.21 & 89.66 & 4.07 & 85.71 \\
\hline Pre-operative care & 2.34 & 10.34 & 2.50 & 14.29 \\
\hline Postoperative Care & 2.76 & 34.48 & 2.50 & 14.29 \\
\hline Mature Women's Health & 2.38 & 13.79 & 2.21 & 7.14 \\
\hline Gynecological oncology & 2.83 & 24.14 & 2.50 & 14.29 \\
\hline Urogynecology \& Pelvic Floor Problems & 3.17 & 41.38 & 3.21 & 35.71 \\
\hline Pediatric \& Adolescent Gynecology & 2.62 & 17.24 & 2.79 & 28.57 \\
\hline Sexual \& Reproductive Health & 2.69 & 27.59 & 2.79 & 28.57 \\
\hline
\end{tabular}

TABLE 3: Importance of each Entrustable Professional Activity (EPA) for Simulationbased Assessment

\section{Discussion}

This Delphi consensus determined the importance of OBGYN EPAs with respect to residency training, set benchmarks for each stage of residency, and identified the role of simulation in both training and assessment. First, a task analysis yielded a list of 15 EPAs for OBGYN based on a review of international curricula. Second, this list was virtually presented as a questionnaire to a North American panel of OBGYN residency program directors and validated through consensus. For the benchmarks, the majority of experts agreed that for each EPA there is a stepwise increase in the level of competence depending on the stage of residency. Most of the panel in this study were neutral about the role of simulation in OBGYN, except for the learning of surgical and procedural skills. Perhaps this may be explained by their current experience and more extensive use of simulation in these specific areas of practice. However, the value of simulation for residency training extends beyond that of purely technical skills. There is a growing body of literature showing its use in team-based training, communication, and crisis-resource management [23-26]. The EPAs listed in this study may have been too broad for the experts to see the potential or the experts may simply be unfamiliar with the different simulations available for medical education. This might make it difficult to confidently include 
or exclude simulation as a relevant modality. Another survey, outlining more specific milestones may elicit a better response.

In the field of medical education, a Delphi consensus is a common way to determine components of a curriculum, develop assessment tools, and define competencies [27-28]. One of the main benefits of the online consensus group is that it has the potential to include a large number of participants from different and dispersed locations, improving feasibility. It is also inexpensive, anonymous, and limits the dominance of certain individuals that can disproportionately influence the group, avoiding direct confrontation of the experts [27]. However, this may limit the potential for discussion and debate [29].

Limitations of the study include low response rates, especially in the second round of the survey (6.55\%), which may affect the generalizability of our results. This may in part be due to the online platform via email, which is often ignored. In the future, a similar survey may yield better response rates if a phone contact rather than email is used, especially if supported by a group with authority, such as the Royal College of Physicians and Surgeons of Canada. In addition, the survey would likely be better addressed to simulation or medical education experts, rather than program directors, which may yield a better response rate. Subgroup analysis based on demographics was not possible, given the small numbers, which may have introduced a geographical bias. We had 40 responses in part 1 and 15 responses in part 2 . Group size in this setting does not depend on statistical power, but rather on group dynamics. Studies have shown that 10-18 participants in a Delphi study is recommended to reach conclusions and that the expertise of the panel may be more important than size [29-30]. Another limitation is missing data: some experts didn't complete all sections. This was taken into account when calculating the means based on the number of responses for each item and not the total responses.

\section{Conclusions}

In the last 15 years, there has been a reform in medical education with the integration of CBME for training. This model focuses on the learner and aims to ensure that all trainees graduate as competent physicians in all aspects of their specialty. With outcomes in mind, abilities, and competencies that each graduate needs are defined and developed into milestones and EPAs. Simulation will become an important and valuable tool in the training and assessment of residents in the CBD program, allowing for direct observation of skills. The results of this study indicate that most experts remain neutral about the role of simulation, except in the context of technical skills. However, this view will likely change as CBD becomes integrated into the curriculum, with more involvement of medical education experts.

With CBD just around the corner in Canada, all medical specialties, including OBGYN, will need to devise EPAs for each stage of residency and set benchmark levels for the trainees. These benchmarks will identify learners reaching milestones at varying speeds, allowing to tailor each learner's needs individually as well as to identify those that would need additional help earlier on. An OBGYN national curriculum based on predefined EPAs and benchmark levels, as well as adequate assessment tools, including simulation, needs to be further explored for CBME to be successful. The results of this study can help inform future curricula.

\section{Additional Information \\ Disclosures}

Human subjects: All authors have confirmed that this study did not involve human participants or tissue. Animal subjects: All authors have confirmed that this study did not involve animal subjects or tissue. Conflicts of interest: In compliance with the ICMJE uniform 
disclosure form, all authors declare the following: Payment/services info: All authors have declared that no financial support was received from any organization for the submitted work. Financial relationships: All authors have declared that they have no financial relationships at present or within the previous three years with any organizations that might have an interest in the submitted work. Other relationships: Dr. Rajesh Aggarwal is a consultant for Applied Medical. .

\section{Acknowledgements}

The authors wish to thank the Blema and Arnold Steinberg Foundation. This research was funded through an unrestricted grant from the Blema and Arnold Steinberg Foundation.

\section{References}

1. Rowe T: Medical education 2.0. J Obstet Gynaecol Can. 2012, 34:1019-1022. 10.1016/S17012163(16)35427-5

2. Caccia N, Nakajima A, Kent N: Competency-based medical education: the wave of the future . J Obstet Gynaecol Can. 2015, 37:349-353. 10.1016/S1701-2163(15)30286-3

3. Caccia N, Nakajima A, Scheele F, Kent N: Competency-based medical education: developing a framework for obstetrics and gynaecology. J Obstet Gynaecol Can. 2015, 37:1104-1112. 10.1016/S1701-2163(16)30076-7

4. Allen V: Listening. J Obstet Gynaecol Can. 2016, 38:104-107. 10.1016/j.jogc.2015.11.006

5. ten Cate O, Scheele F: Competency-based postgraduate training: can we bridge the gap between theory and clinical practice?. Acad Med. 2007, 82:542-547. 10.1097/ACM.0b013e31805559c7

6. Carraccio C, Englander R, Gilhooly J, et al.: Building a framework of entrustable professional activities, supported by competencies and milestones, to bridge the educational continuum. Acad Med. 2016, 10.1097/ACM.0000000000001141

7. Better Education for Obstetrics and Gynecology (BOEG): Dutch National Competency Based Curriculum for Obstetrics \& Gynaecology, English version. Accessed: August 2, 2016: https://www.knmg.nl/web/file?uuid=bea1113c-c9bf-44b5-9c3505da749b1162 \&owner $=5$ c945405-d6ca-4deb-aa16-7af2088aa173\&con....

8. Ten Cate O: Nuts and bolts of entrustable professional activities . J Grad Med Educ. 2013, 5:157-158. 10.4300/JGME-D-12-00380.1

9. Royal College of Physicians and Surgeons of Canada. Competence by Design . 2016, Accessed: July 11, 2018: http://www.royalcollege.ca/rcsite/cbd/competence-by-design-cbd-e.

10. Garofalo M, Aggarwal R: Competency-based medical education and assessment of training: Review of selected national obstetrics and gynaecology curricula. J Obstet Gynaecol Can. 2017, 39:534-544. 10.1016/j.jogc.2017.01.024

11. Queen's University: Competency-based medical education. Accessed: July 13, 2018: https://meds.queensu.ca/academics/cbme.

12. Miller GE: The assessment of clinical skills/competence/performance . Acad Med. 1990, 65:6367. 10.1097/00001888-199009000-00045

13. Sabourin JN, Van Thournout R, Jain V, Demianczuk N, Flood C: Confidence in performing normal vaginal delivery in the obstetrics clerkship: a randomized trial of two simulators. J Obstet Gynaecol Can. 2014, 36:620-627. 10.1016/S1701-2163(15)30542-9

14. Posner G, Bonin B, Nakajmia A: Evaluation of residents' documentation skills after a simulated operative vaginal delivery. J Obstet Gynaecol Can. 2009, 31:1064-1067. 10.1016/S1701-2163(16)34353-5

15. Lopreiato JO: Healthcare Simulation Dictionary. AHRQ. Agency for Healthcare Research and Quality, Rockville, MD; 2016. 16:0043.

16. A Five-Stage Model of the Mental Activities Involved in Directed Skill Acquisition . 1980, Accessed: October 2, 2016: http://www.dtic.mil/dtic/tr/fulltext/u2/a084551.pdf.

17. Eraut M: Developing Professional Knowledge and Competence. Falmer Press, London; Washington D.C; 1994.

18. The obstetrics and gynecology milestone project. J Grad Med Educ. 2014, 6:129-143. 10.4300/JGME-06-01s1-07 
19. Royal College of Physicians and Surgeons of Canada . (CBD Competence Continuum). Accessed: July 13, 2018:

http://www.royalcollege.ca/portal/pls/portal/!PWEB_PORTAL.wwpob_page.show? _docname=2481903.PDF.

20. Zone of Proximal Development. (2012). Accessed: July 13, 2018: https://www.simplypsychology.org/Zone-of-Proximal-Development.html.

21. Snell L, Frank J, Stoneham G, et al.: Competence by Design: Reshaping Canadian Medical Education. Ottawa; 2014.

22. Vygotsky L: Thought and Language. Kozulin A (ed): MIT Press, Cambridge (MA); 1986.

23. Fung L, Boet S, Bould MD, et al.: Impact of crisis resource management simulation-based training for interprofessional and interdisciplinary teams: a systematic review. J Interprof Care. 2015, 29:433-444. 10.3109/13561820.2015.1017555

24. Gillman LM, Brindley P, Paton-Gay JD, et al.: Simulated Trauma and Resuscitation Team Training course-evolution of a multidisciplinary trauma crisis resource management simulation course. Am J Surg. 2016, 212:188-193. 10.1016/j.amjsurg.2015.07.024

25. Siassakos D, Fox R, Bristowe K, et al.: What makes maternity teams effective and safe? Lessons from a series of research on teamwork, leadership and team training. Acta Obstet Gynecol Scand. 2013, 92:1239-1243. 10.1111/aogs.12248

26. van der Nelson HA, Siassakos D, Bennett J, et al.: Multiprofessional team simulation training, based on an obstetric model, can improve teamwork in other areas of health care. Am J Med Qual. 2014, 29:78-82. 10.1177/1062860613485281

27. Humphrey-Murto S, Varpio L, Gonsalves C, Wood TJ: Using consensus group methods such as Delphi and Nominal Group in medical education research. Medical Teacher. 2017, 39:14-19. 10.1080/0142159x.2017.1245856

28. Thangaratinam S, Redman CW: The Delphi technique. Education: The Obstetrician \& Gynaecologist. 2005, 7:120-125. 10.1576/toag.7.2.120.27071

29. Okoli C, Pawlowski SD: The Delphi method as a research tool: an example, design considerations and applications. Inform Manage-Amster. 2004, 42:15-29.

10.1016/j.im.2003.11.002

30. Murphy MK, Black NA, Lamping DL, et al.: Consensus development methods, and their use in clinical guideline development. Health Technol Assess. 1998, 2:1-88. 10.3310/hta2030 